\title{
An Analysis of Ecological Coexistence in Upanișads
}

\author{
Ajay Mohan $\mathrm{M}^{*}$
}

\section{Abstract}

The paper intends to objectively review the ecological understanding of Upanișhadic rșis. Since ecology is a modern notion, it is required to precisely place it within the Upanișhadic thought. For that purpose, a possible ontological structure of Upanișhadic philosophy is sorted in which the discussion of ecology becomes meaningful. Upanișhadic rssis conceived ecology as a part of their metaphysics, that is, one which is assisted by the devatas. There is a dependent coexistence between Devatas, Humans and the world. This feature of Upanișhadic philosophy should not be treated as a declaration for environmental conservation. It is rather seen as a theory of consumption and calibration from both sides. Although ecology is integrated into the Upanișhadic metaphysics, it is not one of the subject matters of Upanişhads. An understanding of ecology traceable from Upanișhads is supplementary to Upanișhadic theory of Devatas. Thus, the author concludes that the Upanișhadic ecology is metaphysical rather than natural.

Keywords: Upaniṣhads, Ecology, Devatas, Brahman, Prāṇa, Dependent Coexistence

\section{Introduction}

Upanișads originated at the juncture of Indian thought and culture which marked the transition from Vedic thought towards the era of

\footnotetext{
University of Hyderabad, Hyderabad, Telangana, India; majaymohan@gmail.com
} 
systems of philosophy. Upanișads retained some of the Vedic world views and it also provided a foundation for the later speculative and analytic traditions in India. This paper deals with how, after stepping out of the Vedic pantheon, Upanișads had constructed a philosophical world view by incorporating insights from ecology. In one way or the other, every philosophical system is influenced by its immediate surroundings. In the Upanișads, the rssis theorized their reciprocation and appropriation with the world around them. Based on the notion of reciprocation, the idea of ecology becomes a substantial part of the Upanișadic world view.

The fundamental challenge in figuring out the world view of Upanișads is that the Upanișadic texts differ in the presentation of philosophical issues. However, there is a common thread that connects all these texts and that is the discourse on Brahman. This could be extended to the understanding of two central topics as Paul Deussen says, "all the thoughts of the Upanishads move around two fundametal ideas. These are (1) the Brahman, and (2) the attman" (1908 p.38). These are the two central topics of discussion in Upanișads. The Upanișads discuss the relation between these two, the categories associated with it and the method of understanding the relation. Thus, the world becomes an important category in this discourse. The concept of the world is presented in the Upanișads in two ways. One of them being the view from the Vedic ritualism whereas some texts about the world cannot be put under the category of ritualism. These texts explain nature in a special way. What makes the philosophy of Upanișads different from the later Vedantic philosophy is the treatment of the explication of these topics. The concept of ecology can be borrowed to make sense of this special way. Thus, the Upanișadic world view can be understood as both ritualistic and ecological.

Can the symbolism concerning nature in Upanișads be understood in terms of ecology? There is definitely a difficulty in understanding a concept from one theoretical domain from a completely different one. Troster points out this as,

... traditional religions cannot be "green," for two important reasons. First of all, there is a qualitative difference between modern and pre-modern technology and how it affects the 
environment in both spatial and temporal terms. Secondly, and more importantly, over the last several hundred years, scientific knowledge of the natural world has developed exponentially, thus creating a world view that is radically different from that of our ancestors. (2013, pp. 380-81)

Even the concept of conservation of ecology would not be the same if applied in an earlier worldview. What, however, could be done is to apply the basic idea of an ecological study which is an inquiry into the phenomenon of interconnection between the different entities of nature. To a great extent, the insights from ecology come in the form of analogical reasoning. Analogy had been recognized as a valid epistemic tool by some of the later theoretical systems. That means the particular analogy has a causal effect on the knowledge that is attained by the comparison. In Mundaka Upanishad, the rși gives an example of a spider and spiderweb to show the relation of Brahman and the world. Just like the cobweb comes out of a spider, the world comes out of Brahman. It is also compared with how crops come out of the earth (Mundaka. 01. 01. 07). The analogy is an integral part of the cognition of The concept of 'coming out' as a representation of the relation. The metaphysical relation between the brahman and the world cannot be explained without paraphrasing it into a familiar category. The analogy functions as a facilitator to imagine the concept of 'coming out' as a plausible one.

If a theory accommodates biological elements into their ontology, then it is expected to explain how the complexity of those elements can be integrated in an informative way into the theoretical framework. For example, some cosmologists have put forward a theory of the anthropic principle by considering the question of the possibility of an intelligent life form in the universe ${ }^{1}$. In this paper, the author intends to trace how Upanișadic r̦șis conceived ecology.

\section{An ecology in the ontology}

The ecology is integrated into the Upanisadic philosophy. The object, the observer and the facilitator of observation has a hidden connection in Upanișads. Jonarden Ganeri calls this hidden 
connection 'the Upanișadic episteme'. It is the relation between the self and the supreme order of things. "The fundamental idea of the Upanișadis is the hidden connections between things, and that knowing what these connections are is a profound source of insight" (Ganeri, 2018). He explains two kinds of such hidden relations. The first is the ritual connection and the other is the consideration of humans as a cosmological map.

The theoretical structure of ritualism in Upanișad is an evolved form of its Vedic counterpart. Vedic ritualism functions with a specific ontology and its main categories are absent in Upanișads.

The world that is procreated from the Vedic deities (Prajapati or purusha) is not well-formed. The world has either of the two defects- the jāmi or the pṛthak. Jāmi is the excess resemblance of entities in the world. Because of this, the entities are not sufficiently differentiated. The concept of prthak is the inverse concept of jāmi. This represents the idea that different things are too dissimilar to be related. While the first idea can be avoided only by diversification the second one can be avoided only by connecting things together.

The ritual activity is intended to reform the structure of the world. It is conducted to complete the creation process. Smith explains this,

For the Vedic priests and metaphysicians, ritual activity does not "symbolize" or "dramatize" reality; it constructs, integrates and constitutes the real. Ritual forms the naturally formless, it connects the inherently disconnected, and it heals the ontological disease of the unreconstructed nature, the state toward which all create things and beings perpetually tend. (Smith, 1998, p.51)

The working principle of ritual is the resemblance between entities in the world. That means, "cosmic prototypes were thought to be manipulated by ritual operations performed on accessible counterparts" (Smith, 1998, p. 53). By performing rituals with the objects resembling its comic parallel, the performer determines to complete the structure of the world. In the Vedic literature, Purusa, Pajapati and other deities exist as embodiments and protectors of 
various principles in the world. This paradigm changes with the Upanișadic philosophy.

The subject of Upanișadic analysis can be broadly categorized as Brahman, the ontological categories, brahmavdya (knowledge of Brahman) and the abstract similarities of objects. While the latter two are epistemological topics the former two belong to metaphysics. There can be socio-political reasons for the concept of Brahman coming to the forefront of the cultural dynamics ${ }^{2}$. Prajapati continues to be counted as a prominent deity, but only inferior to Brahman. The Vedic ontology is somewhat being absorbed into Upanișads. Some fundamental concepts, however, are left unmentioned or replaced. The concept of jāmi or prthak or its equivalents is not found in Upanișads.

No Upanișads is genuinely antagonistic to Vedic world view. But it is treated as a lesser form of activity than that of brahma-vidya.

The apara-vidya is constituted of the 4 Vedas: the Rig, the Yajur, the Sama and the Atharva; (and) The 6 Vedangas: phonetics, rituals, grammar, etymology, metrics and astrology. Now the para-vidya is that which leads to immortality. (Mundaka 1.5)

Those who focus on apara-vidya will only go through the candrayanam and attain candraloka. After the depletion of karmaphala, they return to earth (Praśna 1.9). Those who pursue brahma-vidya obtain the world of sun and that is the home of all creatures (etat vai prāṇānām āyatanam) (Praśna 1.10). Another text mentions that those who know Brahman become Brahman (Mundaka 6.9).

There are texts stating that the Brahman is beyond cognition (Kena 1.3). The description of the nature of Brahman has slight differences in different Upanișads. In Kena Upanișad, there is a story of Brahman appearing before devatas in a ghost form. The story portrays Brahman as the supreme deity. There are texts indicating Brahman as the supreme form of existence. The Upanișads does not let us decide any particular conclusion regarding whether Brahman is the supreme principle or the supreme being or anything particular that can be described. The element of indefinability and 
mystery is embedded in the concept of Brahman. The concept gets more perplexing in saying,

That moves that moves not,

That is far, that is near,

That is inside of everything,

And also outside of everything.

(İsāvāsya 5)

Brahman is the primary creator of the world. What is created can be placed as categories of ontology. There are many descriptions of creation in the principal Upanișads. Among them, the one in brihadāranyaka upanșad is closest to the Vedic ritualism. Death after creating the world decided to sacrifice himself in aśva (horse) form (bṛhadāraṇyaka 1.2).

Another description of creation is that from the sun the fire was produced by virat purușa. From the moon clouds and herbs are produced. From him, vedas are created. From him, devas, men, animals, birds, food, truth, brahmacarya, seven prāṇas, seven flames, seven homas, seven cakras, oceans and mountains are created (Mundaka 3.5-3.9). In another description, the Âtman, the primordial being, desired to create the worlds. He created ambha (place above heaven), mareeca (sky), mara (earth) and àpa (below earth). Then, he created purușa. From the purușa's mouth fire, from nose vāyu, from eyes sun, from ears diśa (direction), from hair vanaspati, from heart moon, from navel mrityu and from semen water emerged. These devats chose respective human organs as their abode (Aitareya 1.1-2.5). In the Praśnopanișad, sage Pippalada gives this description of the Prajapati, by doing penance, uniting rayi and prāna. The sage goes on describing Prajapati as year, month and day (1.4-1.13).

In Mundakopanișad, 15 kalas are mentioned (6.7). In the Praśnopanișad, with the addition of another kala, 16 kalas are mentioned as created. They are prāṇa, śraddha, five elements (ākāśadi..), Indriyam, manas, annam, veeyam, tapas, mantra, karma, loka, nāma. By considering these descriptions, the ontology of the collective metaphysics of the principal Upanișads could be sorted out. It is as follows, 


\begin{tabular}{|c|c|c|c|c|c|}
\hline & & Devatas & & & \\
\hline $\begin{array}{l}\text { Purus a/ } \\
\text { Prajapati }\end{array}$ & $\begin{array}{l}\text { Prāṇ a } \\
\text { Rayi }\end{array}$ & $\begin{array}{l}\text { Sun, Moon, } \\
\text { Fire, air, } \\
\text { water, earth, } \\
\text { diśa, } \\
\text { vanaspati, } \\
\text { mrityu }\end{array}$ & Man & $\begin{array}{l}\text { Animals, } \\
\text { Birds }\end{array}$ & $\begin{array}{l}\text { Mountains, } \\
\text { rivers, oceans }\end{array}$ \\
\hline
\end{tabular}

The category of Man can be further divided into:

Devatas

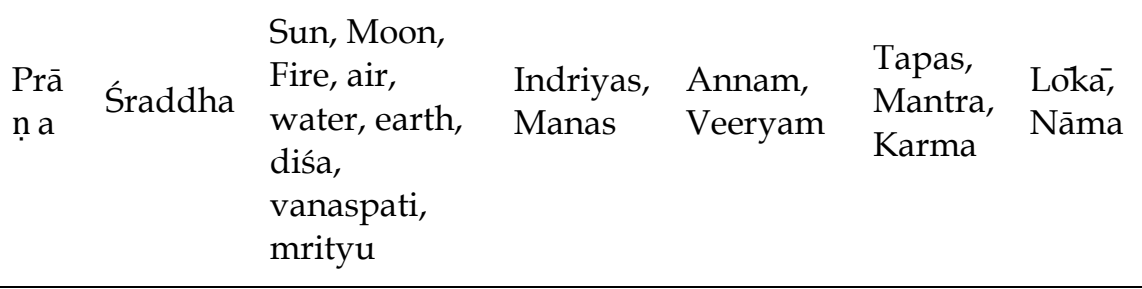

There are two metaphysical dimensions that are applicable to these categories. One is from the perspective of Prajapati being the embodiment of time whereas the other is from the perspective of Purusa as the universal form of being. In both these senses, these categories can be analysed.

Epistemology of Upanișads is concerned with these categories with the addition of Brahman and àtman. Knowledge derived from an abstract interrelation between these elements is a fundamental part of Upanișads.

Prāna and rayi are conceived as two abstract concepts which are manifested in concrete forms. The sun and the moon are expressions of prāna and rayi respectively. When the rays of sun illuminate the world, all beings are rejuvenated (sarvān prānān reșmișu sannidhatte) (praśna 1.6). The presence of devatas in every life form could be deduced from this theory. However, the human body is treated as the apex abode of Devatas. Bṛhadāranyakopanișad treats the sacrificial horse as the embodiment of Prajapati with all the devatas. I do not consider this as an example because this is a special case. The horse here is 
clearly for the sacrificial purpose. Ritualistically, this horse is used to revitalize devatas. Nonetheless, ritualistically, human beings are treated as the center of explanation. However, The Bṛhadāranyaka itself says that there is nothing that is not covered by the Brahman (nainena kiñcanānāvṛtam) (2.5.18).

One of the fundamental theoretical aspects in the Upanișads is its take on ritualism. Another aspect is its philosophical explanations. Upanișadic ritualism is different from the Vedic ritualism precisely due to its theoretical commitments. Methodologically, Upanișadic ritualism and philosophical explanations suppose the possibility of hidden connections between things (Upanișadic episteme). In Upanișads, there are different methods to show this possibility. Upanișads has a method of contemplating the possibility of universal counterparts of a finite process that works. This comparison expands from a less troublesome appropriation of a working process with a natural phenomenon to a complex appropriation of a philosophical theory. The explanation of 'mahasandhis' in Taittiriya is an example of the former (1.3).

Another important technique to figure out the relation, found in Upanișads, is mirroring the human organism with the organism of the world. Aitareya gives this picture,

Agni entered the mouth,

And turned into speech.

Vāyu entered the nostrils,

And became scent.

Sürya entered the eyes,

Became sight.

Diśa (orientation) entered the ears,

Became hearing.

Herbs and trees entered the skin,

Became hair.

Candra entered the heart,

And became mind.

God of death entered the navel,

And turned into apāna.

Varuna entered the reproductive organ, 
And turned into semen.

(Aitareya 2.4)

Bṛhadāranyaka provides a detailed description of this mirroring. The effulgent and immortal being who resides on the external elements are said to reside in the human body also. The effulgent being residing on earth resides in human beings as the corporeal body. Similarly, the shining being in water resides as retas, the fire resides as speech, the sun resides as eye, the directions (Diśa) reside as ears. The moon resides as the mind, lightning resides as tejas, the clouds reside as the sound. The ether resides as the heart, dharma resides as dharma in the body, truth resides as truth in the body, humanity resides as humanity in the body. Finally, the cosmic self is said to reside as ātman in the body. (2.5)

Ontological entities in the Upanișads are related to the devatas residing in each of them. This is something that the Upanișadic rșis agrees upon. An understanding of ecology in Upanișads can be brought out by the above details.

\section{The dependent coexistence}

Ecology is the study of the dependent co-existence of natural entities. In Upanișadic terms, it is the dependent coexistence of the ontological entities of the world through the devatas. A theory of ecology in Upanișads could be generated by describing the nature of this co-existence of the category of man with the world.

Upanișadic ritualism conceives hunger as a primitive category applicable even to devatas. Everything is sustained by the consumption of food. It is stated that "This universe is indeed this much- food and the eater of food" (bri 1.4.6). This act of consumption is treated as both direct and indirect sense. Each devatas are given their share of food. A place is assigned for the hunger and thirst in the devatas (Aitareya 2.5). Brahman created food from water, but it flew away. He tried to catch it with indriyas and manas, but failed. Finally, he caught it with apāna (Aitareya 3.1-10). Devatas indirectly consumes the āhūtis and annam given to agni and apāna. 
This act of consumption is one of the ways the ontological entities coexist. A causal connection can also be traced in Upanișads with this regard. Sun is the causal principle of awakening the world. When the sun sets everything goes to sleep. While sleeping indriyas become one with mind which is a form of moon (Praśna 4.2). Sun is the reason why our eyes are able to see and vayu is the reason why we are breathing. Thus there is a causal chain through which the devats operate.

Devatas function as mutually coexisting entities. As it is stated in Bṛhadāraṇyaka, devatas are dependent on everything and everything is dependent on devatas. Each devatas are described as honey (madhu) to everything and vice versa. The supreme abode of devats which is the human body also dependent on everything else in the world. The human being not only consumes things from outside, but also gives himself back to the earth. At the time of death 15 kalas will return to their respective elements. In chandogya, there is a description of how the disembodied selves after the cessation of karmaphala return to earth. They first reach àkāsa and then they become air. After that, they become smoke and then mist and then cloud. Then they rain down to earth and are born as rice and trees (5.10). From there they enter into other bodies. This is the cycle of life and rebirth. Ecology is a part of this cycle.

\section{Conclusion}

From the aforementioned details, a format of an ecological theory could be figured out from the evidence available in the Upanișads. However, ecology is not an object of discussion in the Upanișads. Upanișadic texts do not suggest any form of value-laden assumptions regarding human interaction with the ecosystem. It neither suggests destruction nor emphasises conservation of ecology. Contrary to this, Madhumita Chatterjee (2016) argues, "Upanishads believed in a supreme, absolute, indivisible underlying reality termed as "Brahman" which manifested itself in every individual beings of the world; pre-supposition of such an entity served as a uniting force between man and nature. 
Consequently, a sense of harmony with the environment, her preservation and development, development of empathy and compassion towards all creatures were repeatedly emphasised in different Upanishadic verses". Despite the fact that there is no repeated emphasis of compassion towards creatures in Upanișads, a sense of harmony is not a necessary consequence of a presupposition of a uniting force. An identification with the other organisms may psychologically result in a sense of empathy and from that it is possible to have a sense of compassion. It is not reasonable to ascribe the result of such a derivation to the original text.

An eco-philosophy that can be traced in the Upanișads is not one that upholds ecological conservation. It could be presumed that a condition of a challenge of ecological destruction or an immediate necessity for a call for environmental conservation was neither popular nor required at the time of Upanișads. It was an ecology of consumption and giving back. It is by the process of giving back that the ecological order was balanced. The entire process is assisted by the devatas. The consumption here does not mean to ravage the ecosystem but to consume as a part of living. This consumption should be in harmony with the devatas. This could be cognized as a metaphysical ecology rather than a natural ecology.

\section{Endnotes}

1. This principle tries to answer the following dilemma: "The properties of our universe have allowed complexity to emerge. .. the biological details of humans and their emergence depend on contingent features of Earth and its history. However, some requirements would seem generic for any form of life" (Livio and Rees 2005), Colyvan and Ginzburg says, "this principle is a selection principle that states that only universes with consciousness in them will have agents capable of wondering about their own and other universes." This was introduced by Brandon Carter in 1973 and he further developed this view in 1983.

2. "Many indications ...point to the fact that the leading ideas of the Upanishads, the doctrine, namely, of the sole reality of the Atman, of its evolution as the universe, its identity with the soul, and so forth, although they may have originated from Brahmans such as Yajnavalkhya, yet in the earliest times met with acceptance rather in 
Ks hatriya circles than among Brahmans, engrossed as the latter were in the ritual. It was only later on that they were adopted by the Brahmans, and interwoven with the ritual on the lines of allegorical interpretation." (Deussen, 1908, p. 8)

\section{References}

Chatterjee, M. (2016). A critical inquiry into ecological visions of ancient India versus, modern West. Tattva- Journal of Philosophy. 8, 2. https://doi.org/ 10.12726

Cohen, S. (2018). The Upaniș ad-A complete guide. New York: Routledge

Deussen, P. (1908). The philosophy of the Upanishads. Edinburg: T.\&T. Clark.

Smith, Brian K (1998). Reflections on resemblance, ritual and religion. Delhi: Motilal Banarsidass.

Troster, L. (2013). What is Eco-Theology? CrossCurrents, 63(4), Toward an Eco-theology. https://doi.org/10.1111/cros.12043 